\title{
Assessment of Physico-chemical Water Quality of Bira Dam, Bati Wereda, Amhara Region, Ethiopia
}

\author{
Tessema $A^{1 *}$, Mohammed $A^{1}$, Birhanu $\mathrm{T}^{2}$ and Negu $\mathrm{T}^{3}$ \\ ${ }^{1}$ Department of Biology, Wollo University, Dessie, Ethiopia \\ ${ }^{2}$ Tehulederie Wereda Office of Water Resource Development, Hayq, Ethiopia
}

${ }^{3}$ Kemissie Zonal Agriculture Office, Ehiopia

\begin{abstract}
Bira dam was constructed in Bati district in 1986 through the aid of International Red Cross Association for food security purpose. The study was conducted from January to September 2013. The objective of the study was to assess physico-chemical parameters of Bira dam. Current total area, average depth of the reservoir were measured using GPS and rope respectively, physico-chemical parameters were taken monthly from January to September 2013 from three sites. Digital Multimetres were used to measure $\mathrm{pH}$, Temperature, conductivity and Turbidity value. SPSS Version 16 was used to analyze the collected data. Univarate test was used to test the physico-chemical parameters difference among sites and months. The mean value of $\mathrm{pH}$, Temperature, Turbidity and conductivity $7.02,24.11^{\circ} \mathrm{C}, 24.60 \mathrm{NTU}$ and $399.00 \mu \mathrm{S} / \mathrm{cm}$ respectively. There was no significant difference in all physico-chemical parameters among sites $(P>0.05)$. There was significant difference in water Temperature, Turbidity and conductivity by month $(P<0.05)$. The current total area of the dam is 18 hectare which was 42 hectare when the dam was constructed; the depth also reduces from 20 to $4.33 \mathrm{~m}$. Since the watershed of the dam is highly degraded, the dam will be totally dried if the situation continues. The turbidity value of Bira dam was higher than most studied dams in Ethiopia, therefore watershed of the dam should be properly managed though full participation of dam users.
\end{abstract}

Keywords: Millimeters; Turbidity; Red cross; Physico-chemical parameters; Conductivity; Association; Temperature

\section{Introduction}

Ethiopia is uniquely rich in water resources. It has numerous water bodies including ponds, lakes, rivers, reservoirs and wetlands. Based on the estimation of FAO [1,2] the surface area of major lakes and reservoirs is $7,334 \mathrm{Km}^{2}$ and the length of rivers is $7,185 \mathrm{~km}$.

Ethiopia could be called a water tower of Eastern Africa in a continent where its most part is arid. The inland water body of Ethiopia is estimated at about $7,400 \mathrm{~km}^{2}$ of lake area and about 7,000 $\mathrm{km}$ total length of [3]. These water bodies contain large population of commercially important fish species. However, the territory of Ethiopia seems to be among regions of the African continent which are least explored in ichtyofauna perspectives [4].

The development of aquatic life (flora and fauna) in surface waters is influenced by a variety of environmental conditions that determine the species as well as the physiological performance of individual organisms. The flora and fauna present in specific aquatic systems are a function of the combined effects of various hydrological, physical and chemical factors [5]. Aquatic ecosystems are dynamic and their tropic state is controlled by physical and chemical conditions. Thus, monitoring and evaluating the tropic state of lakes have become an essential prerequisite to develop control mechanisms.

Expanding human population brought about by the opportunities of good water supply, irrigation, fish production recreation and navigation offered by reservoirs has put enormous pressure and stress on the quality of water impounded by the reservoir. The impact of human activities in and around the reservoir is felt on the unique physical and chemical properties of water on which the sustenance of fish that inhabit the reservoir is built as well as to the functions of the reservoir. Water quality is determined by the physical and chemical limnology of a reservoir [6] and includes all physical, chemical and biological factors of water that influence the beneficial use of the water. Water quality is important in drinking water supply, irrigation, fish production, recreation and other purposes to which the water must have been impounded.

Water quality deterioration in reservoirs usually comes from excessive nutrient inputs, eutrophication, acidification, heavy metal contamination, organic pollution and obnoxious fishing practices. The effects of these "imports" into the reservoir do not only affect the socio-economic functions of the reservoir negatively, but also bring loss of structural biodiversity of the reservoir $[7,8]$ have used the physico-chemical properties of water to assess the water quality of a reservoir. The use of the physico-chemical properties of water to assess water quality gives a good impression of the status, productivity and sustainability of such water body. The changes in physical characteristics like temperature, transparency and chemical elements of water such as dissolved oxygen, chemical oxygen demand, nitrate and phosphate provide valuable information on the quality of the water, the source(s) of the variations and their impacts on the functions and biodiversity of the reservoir.

The quality of surface water has deteriorated in many countries in the past few decades. As a result of the growing population, increasing industry, agriculture, and urbanization, the inland water bodies are confronted with the increasing water demand, as facing with extensive anthropogenic inputs of nutrients and sediments, especially the lakes and reservoirs [9]. To handle this problem, it is necessary to carry out water quality assessment, planning, and management, in which water

*Corresponding author: Tessema A, Wollo University, Department of Biology Dessie, Ethiopia, E-mail: atecklie@yahoo.com

Received June 11, 2014; Accepted June 23, 2014; Published October 03, 2014

Citation: Tessema A, Mohammed A, Birhanu T, Negu T (2014) Assessment of Physico-chemical Water Quality of Bira Dam, Bati Wereda, Amhara Region, Ethiopia. J Aquac Res Development 5: 267. doi:10.4172/2155-9546.1000267

Copyright: (c) 2014 Tessema A, et al. This is an open-access article distributed under the terms of the Creative Commons Attribution License, which permits unrestricted use, distribution, and reproduction in any medium, provided the original author and source are credited. 


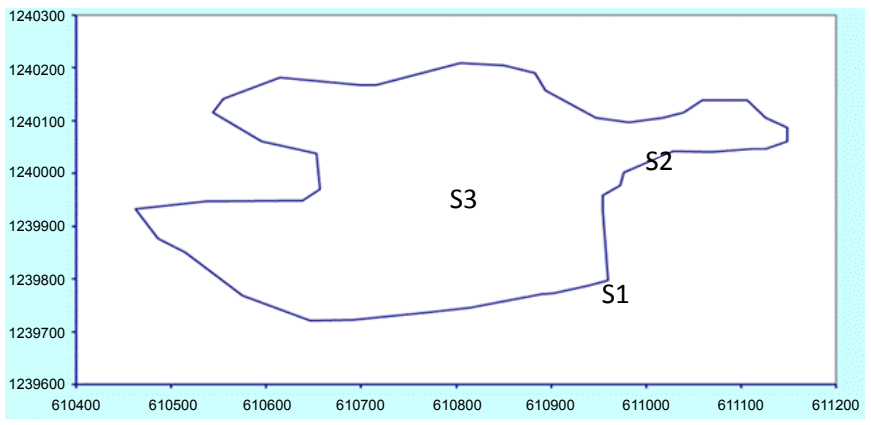

Figure 1: Sketch of Bira dam drawn using the collected $X$-coordinate and Y-coordinate, Longitudes belongs to $\mathrm{X}$-axis and Latitudes belongs to $\mathrm{Y}$-axis. Site1 (S1) is the littoral area without vegetation, Site2 (S2), Littoral area with Typha latifola species coverage and Site3 (S3), the open water, pelagic.

\begin{tabular}{|c|c|c|c|c|c|c|c|}
\hline & & & $\begin{array}{l}\text { Sum of } \\
\text { Squares }\end{array}$ & Df & $\begin{array}{l}\text { Mean } \\
\text { Square }\end{array}$ & $\mathbf{F}$ & Sig. \\
\hline \multirow{3}{*}{$\begin{array}{c}\mathrm{pH}^{*} \\
\text { Month }\end{array}$} & Between Groups & (Combined) & 1.346 & 5 & .269 & 328 & .886 \\
\hline & \multicolumn{2}{|c|}{ Within Groups } & 9.846 & 12 & .821 & & \\
\hline & \multicolumn{2}{|l|}{ Total } & 11.192 & 17 & & & \\
\hline \multirow{3}{*}{$\begin{array}{l}\text { Temp * } \\
\text { Month }\end{array}$} & Between Groups & (Combined) & 62.518 & 5 & 12.504 & 22.574 & .000 \\
\hline & \multicolumn{2}{|c|}{ Within Groups } & 6.647 & 12 & .554 & & \\
\hline & \multicolumn{2}{|l|}{ Total } & 69.165 & 17 & & & \\
\hline \multirow{3}{*}{$\begin{array}{l}\text { Turbidity } \\
\text { * Month }\end{array}$} & Between Groups & (Combined) & 1542.401 & 5 & 308.480 & 4.338 & .017 \\
\hline & \multicolumn{2}{|c|}{ Within Groups } & 853.413 & 12 & 71.118 & & \\
\hline & \multicolumn{2}{|l|}{ Total } & 2395.814 & 17 & & & \\
\hline \multirow{3}{*}{$\begin{array}{l}\text { Con * } \\
\text { Month }\end{array}$} & Between Groups & (Combined) & 12778.000 & 5 & 2555.600 & 48.989 & .000 \\
\hline & \multicolumn{2}{|c|}{ Within Groups } & 626.000 & 12 & 52.167 & & \\
\hline & \multicolumn{2}{|l|}{ Total } & 13404.000 & 17 & & & \\
\hline
\end{tabular}

Table 1: Physico-chemical parameters variation among the different sampling months.

quality monitoring plays an important role [10]. This study aimed at assessing the water quality of Bira dam used for irrigation, livestock watering and fish production using some selected physico-chemical parameters. The results will form the baseline for monitoring and tracking changes in the water quality as a result of the dam's natural dynamics over time and impact of main activities on the dam and its watershed.

\section{Objectives}

\section{General objective}

The main objective of the study was to assess physico-chemical parameters of Bira dam to check the dam suitability for fish stocking.

\section{Specific objective:}

- To assess physico-chemical parameter of Bira dam.

\section{Material and Methods}

\section{Study area}

Bira kebele is one of the kebeles of Bati Woreda where Bira dam is found that was constructed for irrigation purpose by Red Cross. The dam at the beginning when it was constructed had a depth of 15 to $20 \mathrm{~m}$ and a total area of 42 hectare, but recently its area reduced to 18.33 hectares due to siltation (Figure 1). Bati is one of the districts in Oromia zone that has different culture attracting tourists especially on market day, Monday. The economy is based on crop production (sorghum, teff and maize) and livestock rearing. Livestock production is constrained by lack of grazing and access to fodder. Local agricultural labor, migration labor and firewood sale are important income generating activities particularly for poorer households (Figure 1) [11].

\section{Methods}

Physico-chemical parameters: Physico-chemical parameters conductivity in $\mu \mathrm{s} / \mathrm{cm}, \mathrm{pH}$, Turbidity in NTU and temperature in ${ }^{\circ} \mathrm{C}$ were measured using digital multimetres in three sites, S1, S2 and S3 from January to June 2013.

Data analysis: Descriptive Statistics (mean, graphs) and inferential statistics (Univarate analysis) were used through SPSS Version 16 application.

\section{Result and Discussion}

\section{Physico-chemical parameters}

Most of the values of Physico-chemical water quality parameters during sampling months were in the optimum condition for fish production except for higher Turbidity value [12]. As stated below in Table 1, except $\mathrm{pH}$, temperature, conductivity and Turbidity showed significant difference among sampling months $(\mathrm{P}<0.05)$. There were no significant difference in water quality parameters among the three sites $(\mathrm{P}>0.05)$ (Table 2).

\section{pH}

The $\mathrm{pH}$ is an important variable in water quality assessment as it influences many biological and chemical processes within a water body and all processes associated with water supply and treatment [13]. In unpolluted waters, $\mathrm{pH}$ is principally controlled by the balance between the carbon dioxide, carbonate and bicarbonate ions as well as other natural compounds such as humic and fluvic acids. Changes in $\mathrm{pH}$ can indicate the presence of certain effluents, particularly when continuously measured and recorded, together with the conductivity of a water body. Dial variations in $\mathrm{pH}$ can be caused by the photosynthesis and respiration cycles of algae in eutrophic waters. The $\mathrm{pH}$ of most natural waters is between 6.0 and 8.5 , although lower values can occur in dilute waters high in organic content, and higher values in eutrophic waters, Groundwater brines and salt lakes [13]. The desirable $\mathrm{pH}$ range for fish is between 6.5-9. Long term exposure to $\mathrm{pH}$ values beyond these limits slows fish growth and reduces health. Exceedingly alkaline water (greater than $\mathrm{pH} 9$ ) is dangerous as ammonia toxicity increases rapidly. At higher temperatures fish are more sensitive to $\mathrm{pH}$ changes. The mean $\mathrm{pH}$ value of Bira dam ranged from 6.6 -7.3 almost similar with Tekeze dam and lower than Hashenge (8.4). The Bira dam $\mathrm{pH}$ value is suitable for fish production and its variation among sites described in Figure 2.

\section{Water temperature}

Fish are exothermic, their body temperature is about that of the surrounding environment; and affects all metabolic processes. Cold

\begin{tabular}{|c|c|c|c|c|c|}
\hline \multicolumn{2}{|c|}{ Site } & pH & Temperature & Conductivity & Turbidity \\
\hline \multirow{2}{*}{ Site1 } & Mean & 6.9400 & 23.967 & 393.83 & 21.265 \\
\cline { 2 - 6 } & Std. Deviation & .40714 & 2.4977 & 30.413 & 4.7235 \\
\hline \multirow{2}{*}{ Site2 } & Mean & 6.6600 & 24.350 & 401.17 & 25.268 \\
\cline { 2 - 6 } & Std. Deviation & .95714 & 2.0047 & 28.646 & 18.3661 \\
\hline \multirow{2}{*}{ Site3 } & Mean & 7.4667 & 24.033 & 402.00 & 27.258 \\
\cline { 2 - 6 } & Std. Deviation & .86832 & 1.8640 & 29.779 & 9.8578 \\
\hline
\end{tabular}

Table 2: Physico-chemical parameters variation among sampling sites during sampling months. 


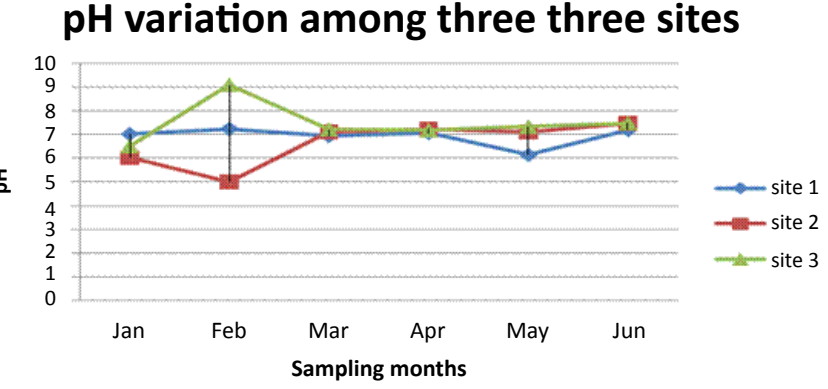

Figure 2: $\mathrm{pH}$ variation among sampling sites during sampling months.

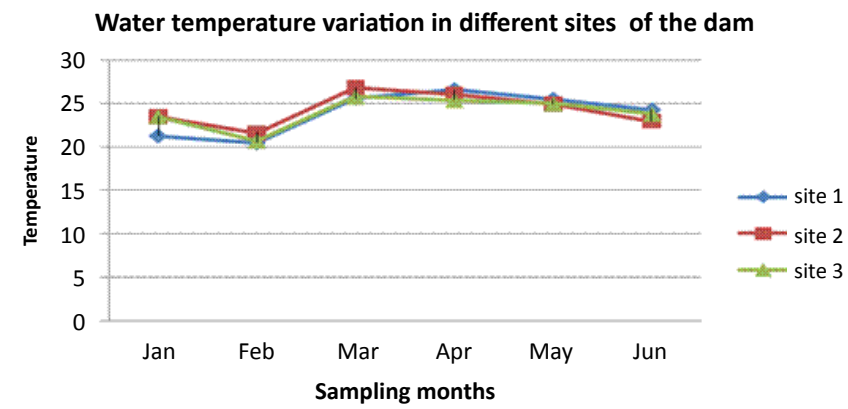

Figure 3: Water temperature variation among sampling sites during sampling periods.

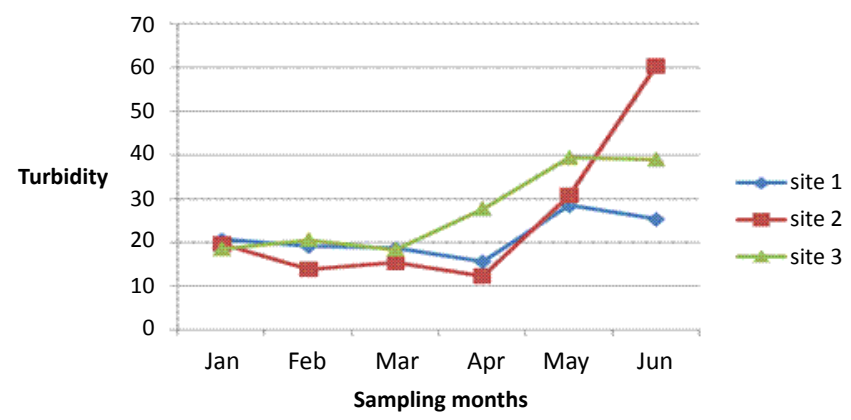

Figure 4: Turbidity variation among sampling sites during sampling periods.

water slows metabolism and warm water increases metabolic rate. Fish have adapted to a wide range of temperatures. Some cold water species can tolerate temperatures below $32^{\circ} \mathrm{F}$; while desert killifish can live in pools in Death Valley at temperatures in excess of $110^{\circ} \mathrm{F}$. Native warm-water fish have a temperature tolerance range of about 34- $104^{\circ} \mathrm{F}$ although many species will become stressed near either of these extremes. There below $55^{\circ} \mathrm{F}$ activity and feeding slow. Above $95^{\circ} \mathrm{F}$ many warm-water fish begin to reach upper lethal temperature tolerance limits. Tropical fish such as the tilapia, cannot tolerate cold water. They become stressed when water reaches $60^{\circ} \mathrm{F}$ and die at water temperatures below $50^{\circ} \mathrm{F}$. Trout and other coldwater fish will die when water temperature exceeds $70^{\circ} \mathrm{F}$. Their optimum temperature is about $55-65^{\circ} \mathrm{F}$ and they are active down to $40^{\circ} \mathrm{F}$. Fish must adjust to temperature changes gradually. A warm-water fish may survive in $100^{\circ} \mathrm{F}$ water if slowly acclimated to it; however, a sudden change from a water temperature of $65^{\circ} \mathrm{F}$ to $75^{\circ} \mathrm{F}$ may shock and kill the fish. The mean water temperature of Bira dam ranged from $23.97-24.35^{\circ} \mathrm{C}$ suitable for common carp fish production. Temperature variation among sampling sites is described in Figure 3.

\section{Turbidity}

Water turbidity refers to the quantity of suspended material, which interferes with light penetration in the water column. In water bodies, water turbidity can result from planktonic organisms or from suspended clay particles. Turbidity limits light penetration, thereby limiting photosynthesis in the bottom layer. Higher turbidity can cause temperature and DO stratification in water bodies. Planktonic organisms are desirable when not excessive, but suspended clay particles are undesirable. It can cause clogging of gills or direct injury to tissues of aquatic organisms. Erosion or the water itself can be the source of small $(1-100 \mathrm{~nm})$ colloidal particles responsible for the unwanted turbidity. The particles repel each other due to negative-charges: this can be neutralized by electrolytes resulting in coagulation. It is reported that alum and ferric sulfate are more effective than hydrated lime and gypsum in removing clay turbidity. Both alum and gypsum have acid reactions and can depress $\mathrm{pH}$ and total alkalinity, so the simultaneous application of lime is recommended to maintain the suitable range of $\mathrm{pH}$. Treatment rates depend on the type of soil. The turbidity value measured in NTU was higher (21.26-27.27) in Bira dam than Tekeze dam (8-11).the bigger difference might be duet to highly degraded watershed of Bira dam resulted higher siltation. Turbidity variation among sites during sampling periods is described in Figure 4.

\section{Conductivity}

The values of Electrical conductivity (EC) ranged from 260 to $300 \mu \mathrm{S} \mathrm{cm}{ }^{-1}$ in Tekeze . Total dissolved Conductivity is related to the concentrations of total dissolved solids and major ions. The conductivity of most freshwaters ranges from 10 to $1000 \mu \mathrm{S} \mathrm{cm}^{-1}$, but may exceed $1000 \mu \mathrm{S} \mathrm{cm}^{-1}$, especially in polluted waters, or those receiving large quantities of land run-off [13]. The conductivity value measured in $\mu \mathrm{S} \mathrm{cm}^{-1}$ was higher (393.83-402.00) than Tekeze dam(260-300) and lower(569) Tendaho reservoir. The higher conductivity in Bira dam and Tendaho reservoir might be their geological characteristics containing many cations. The conductivity variation among sites during sampling duration showed in Figure 5.

\section{Conclusion and Recommendation}

Bira dam is used as source of irrigation water, livestock watering and water for washing clothes and basing. The excessive water extraction day and night without regulation, degraded watershed and absence of buffer zone resulted in siltation are major problems affecting water quality and quantity of the dam. The average depth of the dam

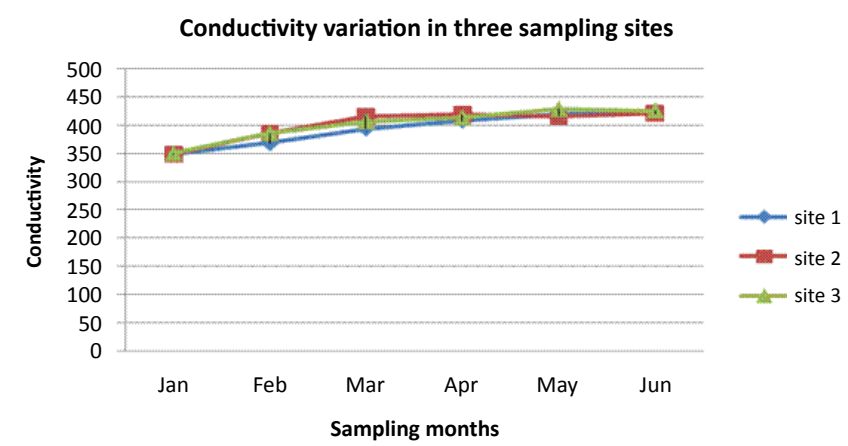

Figure 5: Conductivity variation among sites during sampling period. 
Citation: Tessema A, Mohammed A, Birhanu T, Negu T (2014) Assessment of Physico-chemical Water Quality of Bira Dam, Bati Wereda, Amhara Region, Ethiopia. J Aquac Res Development 5: 267. doi:10.4172/2155-9546.1000267

reduced from 20 metre to $4.33 \mathrm{~m}$ and its total area from 42 hectares to 18 hectares. The dam littoral area mainly is devoid of vegetation that may support fauna and flora including fish species. As a side line activity during data collection Bira dam user association has been established and training on sustainable water utilization and watershed management was delivered to these individuals. All members of the association should actively involve in watershed Bira dam management for sustainable utilization of the resource.

\section{Acknowledgment}

The researchers would like to thank Organizations, Kemissie and Bat Agriculture and Rural Development Offices for positive response during request for transport facilities. We are also delighted to thank Mr.Fisha Woldemariam for his unreserved effort during data collection.

\section{References}

1. FAO (2001) FAO fisheries and aquaculture Ethiopia, Ethiopia.

2. Henderson HF, Welcomme RL (1974) The relationship of yield to MorphoEdaphic-Index and number of fishermen in African inland fisheries. CIFA Occs Pap 1: 19.

3. Imevbore AMA (1970) The chemistry of the River Niger in Kainji Reservoir Area. Arch Hydrobiol 67: 412-431.

4. Golubstov AS, Darkov AA, Dgebuadze YY, Mina MV (1995) An Artificial key to fish species of the Gambela region (The White Nile basin in the limits of Ethiopia). Joint Ethio-Russian Biological expedition, Addis Ababa, Ethiopia, 84.

5. UNESCO (1996) Water Quality Assessments - A Guide to Use Of Biota Sediments and Water in Environmental Monitoring - 2nd edn Deborah Chapman, UK
6. Sidnei MT, Fakio ALT, Maria CR, Francises AE, Adaunto F (1992) Seasonal variation of some limnological factors of Lagoa does Guarana, a Varzea lake of the Rio Paranana State of Mato Groso do Sul, Brazil. Rev Hydrobiol 25: 269-276.

7. Djukic N, Maletin S, Pujin V, Ivanc A, Milajonovic B (1994) Ecological assessment of water quality of Tisze by physico-chemical and biological parameters. Tisca Szeged 28: 37-40.

8. Dumont HJ (1999) The species richness of reservoir plankton and the effect of reservoirs on plankton dispersal (with particular emphasis on rotifers and cladocerans). In: J.G. Tundisi and M. Straskraba edn. Theoretical Reservoir Ecology and its Applications. IIE, Backhuys Publishers, Brazilian Academy of Science: $477-491$.

9. Kondratyev K, Pozdnyakov D V (1998) Water quality remote sensing in the visible spectrum. International Journal of Remote Sensing 19: 957-979.

10. Seker D Z, Goksel C, Kabdasli S, Musaoglu N, Kaya S (2003) Investigation of coastal morphological changes due to river basin characteristics by means of remote sensing and GIS techniques. Water Sci Technol 48: 135-142.

11. Amhara Livelihood Zone Reports (ALZR) (2007) Bati Woreda, Oromiya Administrative Zone. South Wollo \& Oromia Eastern Lowland Sorghum and Cattle Livelihood Zone.

12. Tepe Y, Turkmen A Mutlu E, Ates A (2005) some physico-chemical characteristics of Yarselli Lake, Turkey. Turkish Journal of Fisheries and Aquatic Sciences 5: 35-42.

13. American Public Health Association (APHA) (1995) Standard methods for the examination of water and wastewater, (19thedn). American Public Health Association, Washington DC, USA 